\title{
Pharmacokinetic Drug Interactions Involving Vortioxetine (Lu AA21004), a Multimodal Antidepressant
}

\author{
Grace Chen · Ronald Lee • Astrid-Maria Højer • \\ Jeppe Klint Buchbjerg • Michael Serenko • \\ Zhen Zhao
}

Published online: 23 August 2013

(c) The Author(s) 2013. This article is published with open access at Springerlink.com

\begin{abstract}
Background and Objective The identification and quantification of potential drug-drug interactions is important for avoiding or minimizing the interaction-induced adverse events associated with specific drug combinations. Clinical studies in healthy subjects were performed to evaluate potential pharmacokinetic interactions between vortioxetine (Lu AA21004) and co-administered agents, including fluconazole (cytochrome P450 [CYP] 2C9, CYP2C19 and CYP3A inhibitor), ketoconazole (CYP3A and P-glycoprotein inhibitor), rifampicin (CYP inducer), bupropion (CYP2D6 inhibitor and CYP2B6 substrate), ethinyl estradiol/levonorgestrel (CYP3A substrates) and omeprazole (CYP2C19 substrate and inhibitor).

Methods The ratio of central values of the test treatment to the reference treatment for relevant parameters (e.g., area under the plasma concentration-time curve [AUC]
\end{abstract}

Electronic supplementary material The online version of this article (doi:10.1007/s40261-013-0117-6) contains supplementary material, which is available to authorized users.

\section{G. Chen $(\bowtie) \cdot R$. Lee}

Clinical Pharmacology, Takeda Development Center Americas, One Takeda Parkway, Deerfield, IL 60015, USA

e-mail: grace.chen@takeda.com

\section{A.-M. Højer · J. K. Buchbjerg}

H. Lundbeck A/S, Copenhagen-Valby, Denmark

\section{Serenko}

Pharmacovigilance, Takeda Development Center Americas, One Takeda Parkway, Deerfield, IL 60015, USA

\section{Z. Zhao}

Statistics, Takeda Development Center Americas, One Takeda Parkway, Deerfield, IL 60015, USA and maximum plasma concentration $\left[C_{\max }\right]$ ) was used to assess pharmacokinetic interactions.

Results Co-administration of vortioxetine had no effect on the AUC or $C_{\max }$ of ethinyl estradiol/levonorgestrel or $5^{\prime}$ hydroxyomeprazole, or the AUC of bupropion; the $90 \%$ confidence intervals for these ratios of central values were within 80-125\%. Steady-state AUC and $C_{\max }$ of vortioxetine increased when co-administered with bupropion (128 and $114 \%$, respectively), fluconazole (46 and $15 \%$, respectively) and ketoconazole (30 and $26 \%$, respectively), and decreased by 72 and $51 \%$, respectively, when vortioxetine was coadministered with rifampicin. Concomitant therapy was generally well tolerated; most adverse events were mild or moderate in intensity.

Conclusion Dosage adjustment may be required when vortioxetine is co-administered with bupropion or rifampicin.

\section{Introduction}

Vortioxetine (Lu AA21004; 1-[2-(2,4-dimethylphenylsulfanyl)-phenyl]-piperazine-hydrobromide) is an investigational chemical entity under development by $\mathrm{H}$. Lundbeck A/S and Takeda Global Research \& Development Center, Inc, for the treatment of major depressive disorder (MDD). The in vitro pharmacological profile of vortioxetine is different from that of conventional antidepressants. Vortioxetine is a multimodal compound that is thought to work through a combination of two pharmacological modes of action: serotonin (5-HT) reuptake inhibition and receptor activity. It functions as a $5-\mathrm{HT}_{3}, 5-\mathrm{HT}_{7}$ and $5-\mathrm{HT}_{1 \mathrm{D}}$ receptor antagonist, 5- $\mathrm{HT}_{1 \mathrm{~A}}$ receptor agonist, 5- $\mathrm{HT}_{1 \mathrm{~B}}$ receptor partial agonist and inhibitor of the 5-HT transporter [1]. Preclinical studies demonstrated that vortioxetine enhances levels of the neurotransmitters serotonin, 
noradrenaline, dopamine, acetylcholine and histamine in specific areas of the rat brain (i.e., the ventral hippocampus and medial prefrontal cortex) [1,2]. The recommended dosage for vortioxetine in the treatment of MDD is 5-20 mg/day. In clinical studies, the commonly reported adverse events were nausea, dry mouth, diarrhea, headache, dizziness, somnolence and nasopharyngitis [3-5].

The cytochrome P450 (CYP450) pathway is important for the oxidative metabolism of various drugs and therefore implicated in drug-drug interactions [6, 7]. Such interactions are a major cause of adverse events with pharmacotherapy [8]. Therefore, the identification and quantification of these interactions in vivo is important for avoiding or minimizing the interaction-induced adverse events associated with specific drug combinations. Despite the theoretical potential for serious drug-drug interactions, a recent meta-analysis by Schellander and colleagues [9] showed that the frequency of clinically relevant interactions (e.g., serotonin syndrome, cardiac toxicity) with antidepressants is relatively low.

Vortioxetine undergoes extensive metabolism, primarily via oxidation and subsequent glucuronic acid conjugation. In vitro data suggest that several CYP isoenzymes are involved in the oxidative metabolism of vortioxetine, including CYP2D6, CYP3A4/5, CYP2C9, CYP2C19, CYP2A6, CYP2C8 and CYP2B6 [10]. Vortioxetine is metabolized to its major carboxylic acid metabolite, Lu AA34443 (pharmacologically inactive), mainly via the CYP2D6 pathway. A minor metabolite, Lu AA39835 (hydroxyl metabolite; plasma metabolic ratio $\leq 4 \%$ ), showed similar 5-HT transporter inhibition to the parent compound; however, based on a nonclinical pharmacology study, this metabolite is not expected to penetrate the blood-brain barrier (unpublished results).

Vortioxetine has a favorable pharmacokinetic profile with dose-proportional and linear exposure, moderate oral bioavailability ( $75 \%$; independent of food), extensive tissue distribution (steady-state volume of distribution of approximately $2600 \mathrm{~L})$, and a long elimination half-life (57 h) [11]. Approximately one-third of drug-related material is excreted in the feces, and two-thirds is excreted in the urine (primarily as Lu AA34443 and its glucuronide) [12].

In vitro, vortioxetine and its metabolites did not show any potential for clinically meaningful CYP inhibition given the inhibitory concentration/inhibition constant ratio $\left([I] / K_{\mathrm{i}}\right) \leq 0.024$ for CYP1A2, CYP2A6, CYP2B6, CYP2C8, CYP2C9, CYP2C19, CYP2D6, CYP2E1 or CYP3A4/5. In addition, vortioxetine is not considered a good P-glycoprotein (P-gp) substrate because the in vitro net efflux ratio was much lower than that of the P-gp substrate digoxin (unpublished results).

Although in vitro studies are useful for potential in vivo drug interaction screening [13-15], specific drug-drug interaction studies are required to confirm the magnitude of effect and assess the clinical impact. The primary objectives of the current studies were to explore the effect of extrinsic factors (i.e., concomitant drug administration) on vortioxetine pharmacokinetics and the effect of vortioxetine on the pharmacokinetics of co-administered agents.

\section{Materials and Methods}

\subsection{Study Design}

Four clinical pharmacology studies were performed to evaluate the effect of inhibitors and an inducer of the various CYPs involved in the metabolism of vortioxetine, and three clinical pharmacology studies investigated the inhibitory potential of vortioxetine on various concomitant medications that are CYP substrates. The study designs are summarized in Table 1. The agents investigated in these studies affecting the CYP isoforms involved in vortioxetine metabolism were fluconazole (strong CYP2C19 inhibitor; moderate CYP2C9 and CYP3A4 inhibitor), ketoconazole (strong CYP3A4 and P-gp inhibitor), bupropion (strong CYP2D6 inhibitor), rifampicin (broad CYP inducer) and omeprazole (moderate CYP2C19 inhibitor). The effect of vortioxetine on the pharmacokinetics of omeprazole (CYP2C19 substrate), bupropion (CYP2B6 substrate) and a combined oral contraceptive (COC; CYP3A substrates) was also examined. Subjects provided written informed consent and the study designs were approved by the institutional review board where the study was conducted.

\subsection{Subjects}

The study population consisted of men and women (nonpregnant, nonlactating) aged 18-55 years (18-45 years in the oral contraceptive, bupropion, and omeprazole studies). Subjects were required to have a body mass index of $19-30 \mathrm{~kg} / \mathrm{m}^{2}\left(18-30 \mathrm{~kg} / \mathrm{m}^{2}\right.$ in the oral contraceptive and omeprazole studies). The oral contraceptive study was comprised of healthy nonpregnant women.

\subsection{Effect of Vortioxetine on the Pharmacokinetics of Selected CYP Substrates}

\subsubsection{Combined Oral Contraceptive (CYP3A Substrates)}

This study evaluated the effect of multiple doses of vortioxetine on the pharmacokinetics of once-daily doses of a COC (ethinyl estradiol $30 \mu \mathrm{g} /$ levonorgestrel $150 \mu \mathrm{g}$ ). The study consisted of two 21-day treatment periods, separated by a washout period of 35 days (days 22-56). In sequence 1, subjects received placebo plus COC on days 1 through 21 ; 
Table 1 Summary of study designs

\begin{tabular}{|c|c|c|c|c|c|c|}
\hline $\begin{array}{l}\text { Concomitant } \\
\text { medication }\end{array}$ & Evaluation & Subjects & Study design & Treatment & Sampling time & PK measures \\
\hline \multicolumn{7}{|c|}{ Effect of Vortioxetine on the PK of Selected CYP Substrates } \\
\hline $\begin{array}{l}\text { Ethinyl } \\
\text { estradiol/ } \\
\text { levonorgestrel } \\
\text { (CYP3A } \\
\text { substrate) }\end{array}$ & $\begin{array}{l}\text { Effect of multiple } \\
\text { doses of } \\
\text { vortioxetine on the } \\
\text { steady-state PKs of } \\
\text { COC (ethinyl } \\
\text { estradiol/ } \\
\text { levonorgestrel } \\
\text { [EE/L]) }\end{array}$ & $\begin{array}{l}\text { Healthy } \\
\text { nonpregnant } \\
\text { women, } \\
18-45 \text { years, } \\
\text { BMI } \\
19-30 \mathrm{~kg} / \mathrm{m}^{2} \\
N=28\end{array}$ & $\begin{array}{l}\text { Single-blind, } \\
\text { randomized, } \\
\text { placebo- } \\
\text { controlled, } \\
\text { 2-sequence, } \\
\text { 2-period, } \\
\text { crossover }\end{array}$ & $\begin{array}{l}\text { Placebo }+ \text { EE/L } \\
30 / 150 \mu \mathrm{g} \text { for } 21 \text { days, } \\
\text { then crossover } \\
\text { Vortioxetine } \\
10 \mathrm{mg}+\mathrm{EE} / \mathrm{L} \\
30 / 150 \mu \mathrm{g} \text { for } 21 \text { days, } \\
\text { then crossover }\end{array}$ & $\begin{array}{l}\text { Predose on days } 1,18,19 \\
20,21 \text { then at } 0.5,1,1.5, \\
2,3,4,6,8,10,12,24, \\
36,48,72,96,120,144, \\
168 \mathrm{~h} \text { after last dose on } \\
\text { day } 21\end{array}$ & $\mathrm{AUC}_{24}, C_{\max }$ of $\mathrm{EE} / \mathrm{L}$ \\
\hline $\begin{array}{l}\text { Bupropion } \\
\text { (CYP2B6 } \\
\text { substrate) }\end{array}$ & $\begin{array}{l}\text { Effect of multiple } \\
\text { doses of } \\
\text { vortioxetine on the } \\
\text { steady-state PKs of } \\
\text { bupropion }\end{array}$ & $\begin{array}{l}\text { Healthy adults, } \\
\text { 18-55 years, } \\
\text { BMI } \\
19-30 \mathrm{~kg} / \mathrm{m}^{2} \\
N=60\end{array}$ & $\begin{array}{l}\text { Open-label, } \\
\text { 2-cohort }\end{array}$ & $\begin{array}{l}\text { Cohort 1: see below in } \\
\text { 'Effects of Inhibitors or } \\
\text { Inducers on the PK of } \\
\text { Vortioxetine' } \\
\text { Cohort 2: bupropion } \\
75 \mathrm{mg} \text { twice daily on } \\
\text { days } 1-3 \text {, then } 150 \mathrm{mg} \\
\text { twice daily on days } \\
4-28 \text {; vortioxetine } \\
10 \mathrm{mg} \text { once daily on } \\
\text { days } 15-28\end{array}$ & $\begin{array}{l}\text { Predose and } 1,2,3,4,6,8, \\
12,24 \text { postdose on } \\
\text { days } 14 \text { and } 28\end{array}$ & $\begin{array}{l}\mathrm{AUC}_{24}, C_{\text {max }} \text { of } \\
\text { vortioxetine and } \\
\text { bupropion }\end{array}$ \\
\hline $\begin{array}{l}\text { Omeprazole } \\
\text { (CYP2C19 } \\
\text { substrate) }\end{array}$ & $\begin{array}{l}\text { Effect of multiple } \\
\text { doses of } \\
\text { vortioxetine on the } \\
\text { single-dose PKs of } \\
\text { omeprazole and 5'- } \\
\text { hydroxyomeprazole }\end{array}$ & $\begin{array}{l}\text { Healthy adults, } \\
\text { 18-55 years, } \\
\text { BMI } \\
19-29 \mathrm{~kg} / \mathrm{m}^{2} \\
N=18\end{array}$ & $\begin{array}{l}\text { Open-label, } \\
\text { 1-sequence, } \\
\text { crossover }\end{array}$ & $\begin{array}{l}\text { Omeprazole } 40 \mathrm{mg} \text { on } \\
\text { days } 1 \text { and } 16 ; \\
\text { vortioxetine } 10 \mathrm{mg} \text { on } \\
\text { days } 2-16\end{array}$ & $\begin{array}{l}\text { Day } 1 \text { and day } 16 \text { at pre- } \\
\text { dose and } 0.5,1,1.5,2 \text {, } \\
2.5,3,3.5,4,5,6,7,8 \mathrm{~h} \\
\text { postdose }\end{array}$ & $\begin{array}{l}\mathrm{AUC}_{\infty}, C_{\max } \text { of } \\
\text { omeprazole and } 5^{\prime}- \\
\text { hydroxyomeprazole }\end{array}$ \\
\hline \multicolumn{7}{|c|}{ Effect of Inhibitors or Inducers on the PK of Vortioxetine } \\
\hline $\begin{array}{l}\text { Bupropion } \\
\text { (CYP2D6 } \\
\text { inhibitor) }\end{array}$ & $\begin{array}{l}\text { Effect of multiple } \\
\text { doses of bupropion } \\
\text { on the steady-state } \\
\text { PKs of vortioxetine }\end{array}$ & $\begin{array}{l}\text { Healthy adults, } \\
\text { 18-55 years, } \\
\text { BMI } \\
19-30 \mathrm{~kg} / \mathrm{m}^{2} ; \\
N=60\end{array}$ & $\begin{array}{l}\text { Open-label, } \\
\text { 2-cohort }\end{array}$ & $\begin{array}{l}\text { Cohort 1: vortioxetine } \\
10 \mathrm{mg} \text { once daily on } \\
\text { days } 1-28 \text {; bupropion } \\
75 \mathrm{mg} \text { twice daily on } \\
\text { days } 15-17 \text {, then } \\
\text { bupropion } 150 \mathrm{mg} \text { twice } \\
\text { daily on days } 18-28 \\
\text { Cohort 2: see above in } \\
\text { 'Effect of Vortioxetine } \\
\text { on the PK of Selected } \\
\text { CYP Substrates' }\end{array}$ & $\begin{array}{l}\text { Predose and } 1,2,3,4,6,8, \\
10,12,24 \mathrm{~h} \text { postdose on } \\
\text { days } 14 \text { and } 28\end{array}$ & $\begin{array}{c}\mathrm{AUC}_{24}, C_{\max } \text { of } \\
\text { vortioxetine }\end{array}$ \\
\hline $\begin{array}{l}\text { Omeprazole } \\
\text { (CYP2C19 } \\
\text { inhibitor) }\end{array}$ & $\begin{array}{l}\text { Effect of a single } \\
\text { dose of omeprazole } \\
\text { on the steady-state } \\
\text { PKs of vortioxetine }\end{array}$ & $\begin{array}{l}\text { Healthy adults, } \\
18-55 \text { years, } \\
\text { BMI } \\
19-29 \mathrm{~kg} / \mathrm{m}^{2} \\
N=18\end{array}$ & $\begin{array}{l}\text { Open-label, } \\
\text { 1-sequence, } \\
\text { crossover }\end{array}$ & $\begin{array}{l}\text { Omeprazole } 40 \mathrm{mg} \text { on } \\
\text { days } 1 \text { and } 16 ; \\
\text { vortioxetine } 10 \mathrm{mg} \text { on } \\
\text { days } 2-15\end{array}$ & $\begin{array}{l}\text { Day } 15 \text { and day } 16 \text { at } \\
\text { predose and } 1,2,3,4,5, \\
6,7,8,10,12,16 \mathrm{~h} \\
\text { postdose; days } 2,6,10, \\
12-14 \text { at predose and } \\
\text { days } 17-20 \text { at nominal } \\
\text { timepoints identical to } \\
\text { predose }\end{array}$ & $\begin{array}{c}\mathrm{AUC}_{24}, C_{\max } \text { of } \\
\text { vortioxetine }\end{array}$ \\
\hline $\begin{array}{l}\text { Fluconazole } \\
\text { (CYP2C19, } \\
\text { CYP2C9 and } \\
\text { CYP3A4/5 } \\
\text { inhibitor); } \\
\text { ketoconazole } \\
\text { (CYP3A and } \\
\text { P-gp inhibitor) }\end{array}$ & $\begin{array}{l}\text { Effect of multiple } \\
\text { doses of } \\
\text { fluconazole or } \\
\text { ketoconazole on the } \\
\text { single-dose PKs of } \\
\text { vortioxetine }\end{array}$ & $\begin{array}{l}\text { Healthy adults, } \\
18-55 \text { years, } \\
\text { BMI } \\
19-30 \mathrm{~kg} / \mathrm{m}^{2} \\
N=36\end{array}$ & $\begin{array}{l}\text { Open-label, } \\
\text { randomized, } \\
\text { 1-sequence }\end{array}$ & $\begin{array}{l}\text { Vortioxetine } 10 \mathrm{mg} \text { once } \\
\text { daily on days } 1 \text { and } 21 \text {; } \\
\text { fluconazole } 200 \mathrm{mg} \\
\text { once daily or } \\
\text { ketoconazole } 400 \mathrm{mg} \\
\text { once daily on days } \\
15-21\end{array}$ & $\begin{array}{l}\text { Days } 1 \text { and } 21 \text { at predose } \\
\text { and } 1,2,3,4,5,6,8,10, \\
12,16,24,36,48,72, \\
96,120 \mathrm{~h} \text { postdose }\end{array}$ & $\begin{array}{l}\mathrm{AUC}_{\text {last }}, \mathrm{AUC}_{\infty}, \\
C_{\max } \text { of } \\
\text { vortioxetine }\end{array}$ \\
\hline $\begin{array}{l}\text { Rifampicin } \\
\text { (broad CYP } \\
\text { inducer) }\end{array}$ & $\begin{array}{l}\text { Effect of multiple } \\
\text { doses of rifampicin } \\
\text { on the single-dose } \\
\text { PKs of vortioxetine }\end{array}$ & $\begin{array}{l}\text { Healthy adults, } \\
18-55 \text { years, } \\
\text { BMI } \\
19-30 \mathrm{~kg} / \mathrm{m}^{2} ; \\
N=13\end{array}$ & $\begin{array}{l}\text { Open-label, } \\
\text { 1-sequence }\end{array}$ & $\begin{array}{l}\text { Vortioxetine } 20 \mathrm{mg} \text { on } \\
\text { days } 1 \text { and } 25 ; \\
\text { rifampicin } 600 \mathrm{mg} \text { once } \\
\text { daily on days } 15-25\end{array}$ & $\begin{array}{l}\text { Days } 1-6 \text { and } 25-30 \\
\text { predose and } 1,2,3,4,5 \text {, } \\
6,8,10,12,16,24,36, \\
48,72,96,120 \mathrm{~h} \\
\text { postdose on Days } 1 \text { and } \\
25\end{array}$ & $\begin{array}{l}\mathrm{AUC}_{\text {last }}, \mathrm{AUC}_{\infty}, \\
C_{\max } \text { of } \\
\text { vortioxetine }\end{array}$ \\
\hline
\end{tabular}

$A U C_{\text {last }}$ area under the plasma concentration-time curve from time zero to time of last measurable concentration, $A U C_{\infty}$ AUC from time zero to infinity, $A U C_{24}$ AUC from time zero to time $24 \mathrm{~h}, B M I$ body mass index, $C_{\text {max }}$ maximum observed plasma concentration, $C O C$ combined oral contraceptive, $C Y P$ cytochrome $\mathrm{P} 450$, EE/L ethinyl estradiol/levonorgestrel, $P$-gp P-glycoprotein, $P K$ pharmacokinetic/pharmacokinetics 
following the 35-day washout period, they received vortioxetine $10 \mathrm{mg}$ plus $\mathrm{COC}$ for 21 days. In sequence 2 , subjects received vortioxetine $10 \mathrm{mg}$ plus COC on days 1 through 21 ; after the 35-day washout, they received placebo plus COC for 21 days. Blood samples were obtained before dosing on days $1,18,19,20$, and 21 , and then serially, beginning after the last dose on day 21 , for the subsequent $168 \mathrm{~h}$.

\subsubsection{Antidepressant (Bupropion [CYP2B6 Substrate])}

One objective of the bupropion drug interaction study (cohort 2) was to assess the effect of multiple dosing of vortioxetine on the steady-state pharmacokinetics of bupropion (a CYP2B6 substrate). Subjects in cohort 2 received bupropion $75 \mathrm{mg}$ twice daily on days $1-3$, followed by bupropion $150 \mathrm{mg}$ twice daily on days $4-14$. On days $15-28$, they received vortioxetine $10 \mathrm{mg}$ once daily plus bupropion $150 \mathrm{mg}$ twice daily. Serial blood samples were obtained for up to $24 \mathrm{~h}$ postdose on days 14 and 28 to determine plasma concentrations of bupropion and its metabolites. (Cohort 1 is described in the next section.)

\subsubsection{Omeprazole (CYP2C19 Substrate)}

This study was designed primarily to evaluate the effect of multiple doses of vortioxetine on the single-dose pharmacokinetics of omeprazole (CYP2C19 substrate) and its primary metabolite, 5'-hydroxyomeprazole. Subjects received a single dose of omeprazole $40 \mathrm{mg}$ alone (day 1), then 14 days of vortioxetine $10 \mathrm{mg}$ daily alone (days 2-15), followed by a single dose of omeprazole $40 \mathrm{mg}$ in combination with vortioxetine $10 \mathrm{mg}$ (day 16). Serial blood samples were collected for up to $8 \mathrm{~h}$ postdose on days 1 and 16 to determine plasma concentrations of omeprazole and $5^{\prime}$-hydroxyomeprazole.

\subsection{Effect of Inhibitors or Inducers}

on the Pharmacokinetics of Vortioxetine

\subsubsection{Antidepressant (Bupropion [CYP2D6 Inhibitor])}

The second objective (cohort 1) of the bupropion drug interaction study previously mentioned was to evaluate the effect of multiple dosing of bupropion (CYP2D6 inhibitor) on the steady-state pharmacokinetics of vortioxetine. Subjects in cohort 1 received vortioxetine $10 \mathrm{mg}$ once daily on days 1 through 14 . Subsequently, they received vortioxetine $10 \mathrm{mg}$ once daily plus bupropion $75 \mathrm{mg}$ twice daily (on days 15-17), followed by vortioxetine $10 \mathrm{mg}$ once daily plus bupropion $150 \mathrm{mg}$ twice daily (on days 18-28). Serial blood samples were obtained for up to $24 \mathrm{~h}$ postdose on days 14 and 28 to determine plasma concentrations of vortioxetine.

\subsubsection{Omeprazole (CYP2C19 Inhibitor)}

This study explored the effect of a single dose of omeprazole (CYP2C19 inhibitor) on the pharmacokinetics of vortioxetine. Subjects received a single dose of omeprazole $40 \mathrm{mg}$ alone (day 1), then 14 days of vortioxetine $10 \mathrm{mg}$ daily alone (days 2-15), followed by a single dose of omeprazole $40 \mathrm{mg}$ with vortioxetine $10 \mathrm{mg}$ (day 16). In addition to the blood samples collected for omeprazole and $5^{\prime}$-hydroxyomeprazole concentrations (used in the substrate study), serial blood samples were collected for up to $24 \mathrm{~h}$ on days 15 and 16 to determine plasma concentrations of vortioxetine.

\subsubsection{Oral Antifungals: Fluconazole (Strong CYP2C19 Inhibitor; Moderate CYP2C9 and CYP3A4/5 Inhibitor) and Ketoconazole (Strong CYP3A and P-gp Inhibitor)}

This study assessed the effect of multiple doses of fluconazole or ketoconazole on the single-dose pharmacokinetics of vortioxetine. Subjects were randomized to one of two treatment groups (fluconazole or ketoconazole) and received a single dose of vortioxetine $10 \mathrm{mg}$ on day 1 . Following a 14-day washout, subjects received a oncedaily dose of either fluconazole $(200 \mathrm{mg}$ ) or ketoconazole (400 mg) on days 15-21. Subjects in both groups received a single dose of vortioxetine $10 \mathrm{mg}$ on day 21 . Serial blood samples were collected on days 1-6 and days 21-26 to determine plasma concentrations of vortioxetine.

\subsubsection{Antimycobacterial: Rifampicin (Broad CYP Inducer)}

This study examined the effect of multiple doses of rifampicin on the single-dose pharmacokinetics of vortioxetine. On day 1 , subjects received one dose of vortioxetine $20 \mathrm{mg}$. Following a washout period that concluded on day 14 , subjects received rifampicin $600 \mathrm{mg}$ once daily from days 15-25. Subjects also received a single dose of vortioxetine $20 \mathrm{mg}$ on day 25 . Serial blood samples were collected on days 1-6 and days 25-30 before dosing, and for up to $120 \mathrm{~h}$ following the vortioxetine dose on day 25 .

\subsection{Bioanalytical Methods}

\subsubsection{Vortioxetine and Metabolites}

Blood samples for the determination of plasma concentrations of vortioxetine and its metabolites Lu AA34443 and Lu AA39835 in these studies were collected in Vacutainers ${ }^{\circledR}$ containing ethylenediaminetetraacetic acid (EDTA). Plasma samples were stored at $-20{ }^{\circ} \mathrm{C}$ or lower prior to the analysis at Aptuit Ltd., Edinburgh, Scotland. Plasma samples were 
prepared by solid phase extraction using Varian SPEC C8 cartridges in a 96-well plate format. This was followed by separation of the analytes by high-performance liquid chromatography (HPLC) on an Ionosper 5C ion exchange column. The mobile phase consisted of $70 \mathrm{mmol} / \mathrm{L}$ ammonium formate $(\mathrm{pH} 3)$ and acetonitrile (12:88). Eluting compounds were detected by tandem mass spectrometry in the positive ion mode. The internal standards were the ${ }^{13} \mathrm{C}$-labeled analogs of each of these three analytes. The linear ranges for vortioxetine, Lu AA34443 and Lu AA39835 were 0.08 to $80 \mathrm{ng} / \mathrm{mL}$, 0.2 to $200 \mathrm{ng} / \mathrm{mL}$ and 0.04 to $40 \mathrm{ng} / \mathrm{mL}$, respectively, except for the omeprazole drug interaction study where the linear ranges were 0.4 to $100 \mathrm{ng} / \mathrm{mL}, 2$ to $500 \mathrm{ng} / \mathrm{mL}$ and 0.04 to $40 \mathrm{ng} / \mathrm{mL}$, for vortioxetine and metabolites, respectively. The accuracy and precision for these analytes were within 90.0 to $109.0 \%$ and 3.20 to $10.7 \%$, respectively. The lower limits of quantification were the lower end of the linear ranges for all above assays. The bioanalytical methods used for these clinical drug-drug interaction studies were adequate to characterize the plasma concentration profiles of vortioxetine and its metabolites (see Electronic Supplementary Material).

\subsubsection{Interacting Drugs and Metabolites}

Blood samples for the determination of plasma concentrations of interacting drugs and their metabolites in these studies were collected in Vacutainers ${ }^{\circledR}$ containing EDTA (ketoconazole, fluconazole, bupropion and omeprazole), sodium heparin (rifampicin) or potassium oxalate/sodium fluoride (ethinyl estradiol and levonorgestrel). Plasma samples were stored at $-20{ }^{\circ} \mathrm{C}$ or lower prior to the analysis at PPD, Middleton, Wisconsin, except for the omeprazole study where the bioanalysis was conducted at Aptuit Ltd., Edinburgh, Scotland. A liquid chromatography with tandem mass spectrometric detection method was used to analyze each of these interaction drugs in plasma according to the validated method from PPD or Aptuit (proprietary information). The linear range, accuracy and precision of these analyses were considered adequate to determine the plasma concentrations of the interacting drug and metabolite(s) in these studies (see Electronic Supplementary Material).

\subsection{Pharmacokinetic Assessments}

Pharmacokinetic parameters were derived using noncompartmental methods with WinNonlin ${ }^{\circledR}$ (Pharsight Corporation, Mountain View, CA, USA), including the area under the plasma concentration-time curve (AUC) from time zero to time of last measurable concentration $\left(\mathrm{AUC}_{\text {last }}\right)$, the $\mathrm{AUC}$ from time zero to infinity $\left(\mathrm{AUC}_{\infty}\right)$, the AUC from time zero to time $24 \mathrm{~h}\left(\mathrm{AUC}_{24}\right.$; AUC from time zero to time $12 \mathrm{~h}\left[\mathrm{AUC}_{12}\right]$ for bupropion) and the observed maximum plasma concentration $\left(C_{\max }\right)$.

\subsection{Statistical Analyses}

To assess the potential effect of vortioxetine on oral contraceptives, analysis of variance with fixed effects for sequence, period and treatment, and a random effect for subject nested within sequence, was performed on the natural logarithm of pharmacokinetic parameters. The effect of an inhibitor or inducer on vortioxetine was analyzed using a mixed-effects model with treatment as a fixed effect, and subject as a random-effect parameter. The ratio of central values of the test treatment (vortioxetine + inhibitor/inducer) to the reference treatment (vortioxetine alone) for relevant pharmacokinetic parameters (e.g., AUCs and $C_{\max }$ ) was obtained by taking the antilog of the difference between the least-squares (LS) means of test treatment and reference treatment on the natural logarithmic scale. The $90 \%$ confidence interval (CI) of the ratio of central values was obtained by taking the antilog of the $90 \%$ CI for the difference between the LS means of test treatment (vortioxetine + inhibitor/inducer) and reference treatment (vortioxetine alone) on the natural logarithmic scale. The no-effect boundary for $90 \%$ CI for pharmacokinetic parameters was between 80 and $125 \%$. The effect of vortioxetine on other drugs was assessed in a similar fashion.

\section{Results}

\subsection{Effect of Vortioxetine on the Pharmacokinetics} of Selected CYP Substrates

The effect of multiple doses of vortioxetine on the pharmacokinetics of concomitant agents is summarized in Fig. 1 and Table 2. As illustrated, steady-state concentrations of vortioxetine had no clinically meaningful effect on steady-state pharmacokinetic parameters of ethinyl estradiol/levonorgestrel, bupropion or single-dose pharmacokinetics of omeprazole. This was evidenced by $90 \% \mathrm{CI}$ for the central values for ethinyl estradiol and levonorgestrel (CYP3A substrates) and 5'-hydroxyomeprazole (CYP2C19-mediated omeprazole metabolite) $C_{\max }$ and AUC, and bupropion (CYP2B6 substrate) and omeprazole (CYP2C19 substrate) AUC falling within the 80 to $125 \%$ no-effect boundaries when the COC, bupropion or omeprazole was given with vortioxetine compared to without vortioxetine. The $90 \% \mathrm{CI}$ for the central values for bupropion (or its metabolites, threohydrobupropion and erythrohydrobupropion) or omeprazole $C_{\max }$ were just above the no-effect upper boundary of $125 \%$. The $C_{\max }$ values for bupropion and omeprazole, when either compound was given with vortioxetine, were 18 and $11 \%$, respectively, greater than the values for bupropion or omeprazole when given without vortioxetine. 
Fig. 1 Impact of vortioxetine on the pharmacokinetics of coadministered drugs. LS means and $90 \% \mathrm{CI}$ are shown. Dotted lines represent the standard equivalence criterion: $0.80-1.25$ rate limits for the $90 \%$ CIs. $A U C$ area under the plasma concentration-time curve, $C I$ confidence interval, $C_{\max }$ maximum observed plasma concentration, $C Y P$ cytochrome $\mathrm{P} 450, L S$ least-squares

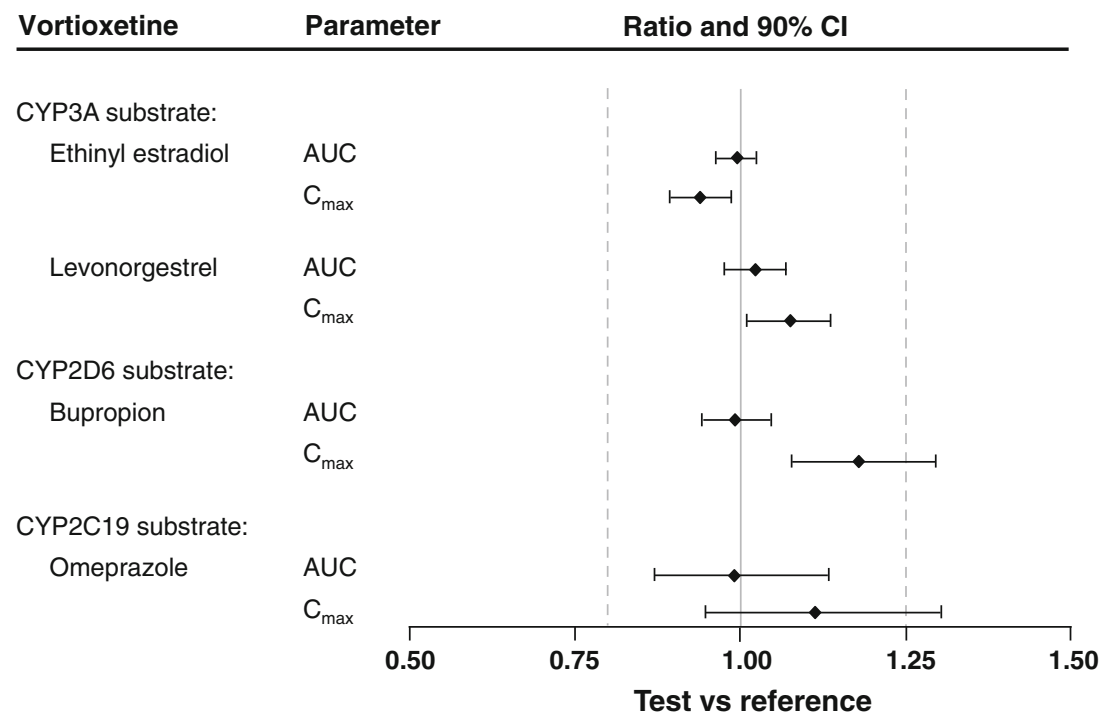

Table 2 Effect of multiple doses of vortioxetine on the pharmacokinetics of concomitant agents

\begin{tabular}{|c|c|c|c|c|c|c|}
\hline \multirow{2}{*}{$\begin{array}{l}\text { Pharmacokinetic parameter of } \\
\text { concomitant agent }\end{array}$} & \multicolumn{4}{|c|}{ Least-squares mean } & \multirow[t]{2}{*}{ Ratio (Test/reference) } & \multirow[t]{2}{*}{$90 \% \mathrm{CI}^{\mathrm{a}}$} \\
\hline & $n$ & $\begin{array}{l}\text { Concomitant agent alone } \\
\text { (reference) }\end{array}$ & $n$ & $\begin{array}{l}\text { Vortioxetine }+ \text { concomitant } \\
\text { agent (test) }\end{array}$ & & \\
\hline \multicolumn{7}{|l|}{ Ethinyl estradiol \pm vortioxetine } \\
\hline $\mathrm{AUC}_{24}(\mathrm{pg} \cdot \mathrm{h} / \mathrm{mL})$ & 27 & 857 & 26 & 850 & 99.19 & $96.20,102.28$ \\
\hline$C_{\max }(\mathrm{pg} / \mathrm{mL})$ & 27 & 86.9 & 26 & 81.6 & 93.87 & $89.31,98.66$ \\
\hline \multicolumn{7}{|l|}{ Levonorgestrel \pm vortioxetine } \\
\hline $\mathrm{AUC}_{24}(\mathrm{pg} \cdot \mathrm{h} / \mathrm{mL})$ & 27 & 86,835 & 26 & 88,629 & 102.07 & $97.58,106.75$ \\
\hline$C_{\max }(\mathrm{pg} / \mathrm{mL})$ & 27 & 6757 & 26 & 7233 & 107.06 & $100.85,113.65$ \\
\hline \multicolumn{7}{|l|}{ Bupropion \pm vortioxetine } \\
\hline $\mathrm{AUC}_{24}(\mathrm{ng} \cdot \mathrm{h} / \mathrm{mL})$ & 28 & 791 & 21 & 785 & 99.22 & $94.12,104.60$ \\
\hline$C_{\max }(\mathrm{ng} / \mathrm{mL})$ & 28 & 150 & 21 & 177 & 117.98 & $107.71,129.23$ \\
\hline \multicolumn{7}{|l|}{ Omeprazole \pm vortioxetine } \\
\hline $\mathrm{AUC}_{\infty}(\mathrm{ng} \cdot \mathrm{h} / \mathrm{mL})$ & 15 & 1108 & 15 & 1046 & 99.0 & $87.0,113$ \\
\hline$C_{\max }(\mathrm{ng} / \mathrm{mL})$ & 15 & 550 & 15 & 617 & 111 & $94.7,130$ \\
\hline \multicolumn{7}{|l|}{$5^{\prime}$-Hydroxyomeprazole } \\
\hline $\mathrm{AUC}_{\infty}(\mathrm{ng} \cdot \mathrm{h} / \mathrm{mL})$ & 15 & 997 & 15 & 976 & 97.9 & $91.2,105$ \\
\hline$C_{\max }(\mathrm{ng} / \mathrm{mL})$ & 15 & 392 & 15 & 411 & 104 & $92.5,116$ \\
\hline
\end{tabular}

$A U C_{\infty}$ area under the plasma concentration-time curve from time zero to infinity, $A U C_{24}$ AUC from time zero to time $24 \mathrm{~h}, C I$ confidence interval, $C_{\max }$ maximum observed plasma concentration

${ }^{a}$ The pharmacokinetic parameters were log-transformed prior to analysis, and the least-squares means, ratios, and corresponding CIs of pharmacokinetic parameters were back-transformed from the log scale

\subsection{Effect of Inhibitors or Inducers} on the Pharmacokinetics of Vortioxetine

The effects of inhibitor/inducer agents on the pharmacokinetics of vortioxetine are summarized in Fig. 2 and Table 3. Following co-administration of a single dose of vortioxetine after multiple doses of fluconazole (CYP2C19, CYP2C9 and CYP3A4/5 inhibitor), ketoconazole (CYP3A and P-gp inhibitor) or bupropion (CYP2D6 inhibitor), the $90 \%$ CIs for vortioxetine AUCs and $C_{\max }$ central values were mostly above the $125 \%$ no-effect boundary, compared with vortioxetine alone. The $90 \%$ CI for vortioxetine $C_{\max }$ and AUC central values were below the $80 \%$ noeffect boundary when vortioxetine was administered with multiple doses of rifampicin (broad CYP inducer) compared with vortioxetine alone. Increases in vortioxetine 
Fig. 2 Impact of coadministered drugs on the pharmacokinetics of vortioxetine. LS means and $90 \% \mathrm{CI}$ are shown. Dotted lines represent the standard equivalence criterion: $0.80-1.25$ rate limits for the $90 \%$ CIs. $A U C$ area under the plasma concentration-time curve, $C I$ confidence interval, $C_{\max }$ maximum observed plasma concentration, $C Y P$ cytochrome P450, LS least-squares, $P$-gp P-glycoprotein

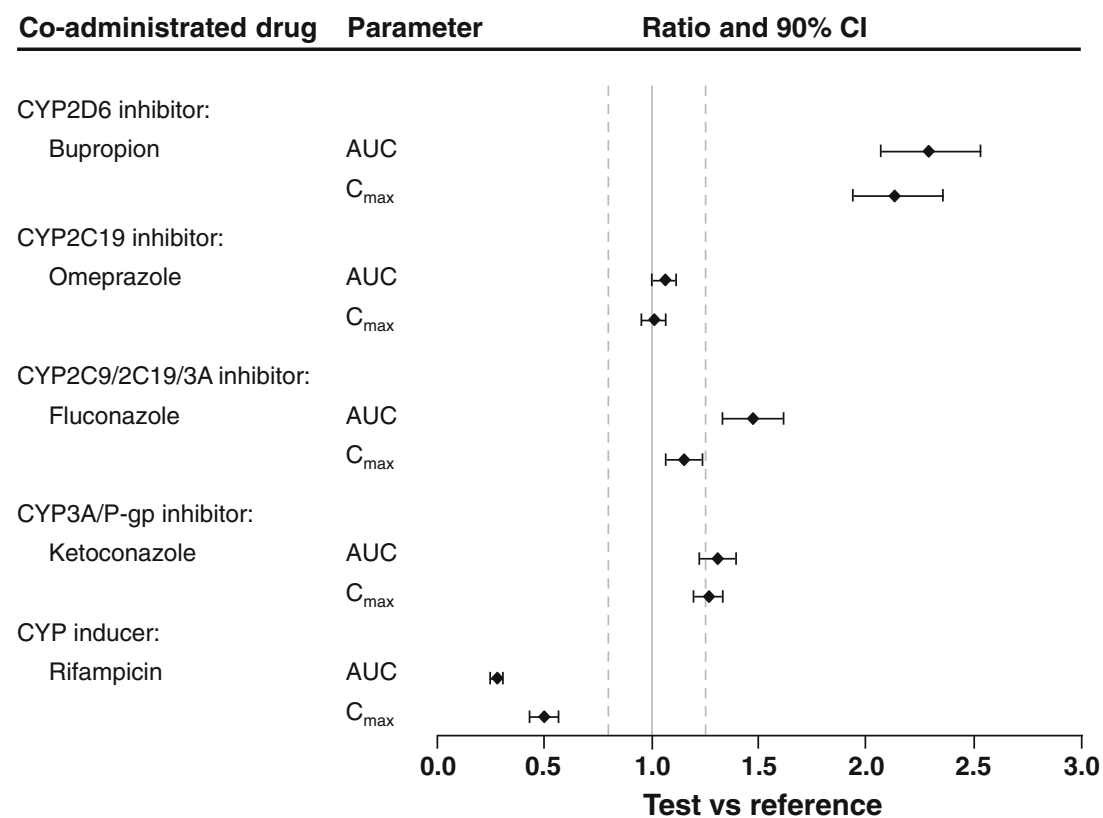

Table 3 Effect of multiple doses of concomitant agents on the pharmacokinetics of vortioxetine

\begin{tabular}{|c|c|c|c|c|c|c|}
\hline \multirow{2}{*}{$\begin{array}{l}\text { Pharmacokinetic parameter } \\
\text { of vortioxetine }\end{array}$} & \multicolumn{4}{|c|}{ Least-squares mean } & \multirow[t]{2}{*}{ Ratio(Test/reference) } & \multirow[t]{2}{*}{$90 \% \mathrm{CI}^{\mathrm{a}}$} \\
\hline & $n$ & $\begin{array}{l}\text { Vortioxetine alone } \\
\text { (reference) }\end{array}$ & $n$ & $\begin{array}{l}\text { Vortioxetine }+ \\
\text { concomitant agent (test) }\end{array}$ & & \\
\hline \multicolumn{7}{|l|}{ Vortioxetine \pm bupropion } \\
\hline $\mathrm{AUC}_{24}(\mathrm{ng} \cdot \mathrm{h} / \mathrm{mL})$ & 28 & 308 & 24 & 702 & 228.30 & $206.51,252.40$ \\
\hline$C_{\max }(\mathrm{ng} / \mathrm{mL})$ & 28 & 15.9 & 25 & 34.0 & 213.57 & $193.66,235.53$ \\
\hline \multicolumn{7}{|l|}{ Vortioxetine \pm omeprazole } \\
\hline $\mathrm{AUC}_{24}(\mathrm{ng} \cdot \mathrm{h} / \mathrm{mL})$ & 15 & 243 & 15 & 256 & 105.5 & $100.5,110.8$ \\
\hline$C_{\max }(\mathrm{ng} / \mathrm{mL})$ & 15 & 13.8 & 15 & 13.9 & 100.5 & $94.9,106.3$ \\
\hline \multicolumn{7}{|l|}{ Vortioxetine \pm fluconazole } \\
\hline $\mathrm{AUC}_{\text {last }}(\mathrm{ng} \cdot \mathrm{h} / \mathrm{mL})$ & 16 & 222 & 16 & 324 & 146.17 & $132.64,161.08$ \\
\hline$C_{\max }(\mathrm{ng} / \mathrm{mL})$ & 16 & 4.52 & 16 & 5.18 & 114.64 & $106.64,123.24$ \\
\hline \multicolumn{7}{|l|}{ Vortioxetine \pm ketoconazole } \\
\hline $\mathrm{AUC}_{\text {last }}(\mathrm{ng} \cdot \mathrm{h} / \mathrm{mL})$ & 17 & 262 & 17 & 342 & 130.48 & $122.34,139.15$ \\
\hline$C_{\max }(\mathrm{ng} / \mathrm{mL})$ & 17 & 4.92 & 17 & 9.00 & 125.73 & $119.20,132.62$ \\
\hline \multicolumn{7}{|l|}{ Vortioxetine \pm rifampicin } \\
\hline $\mathrm{AUC}_{\text {last }}(\mathrm{ng} \cdot \mathrm{h} / \mathrm{mL})$ & 14 & 438 & 14 & 199 & 27.74 & $25.19,30.55$ \\
\hline$C_{\max }(\mathrm{ng} / \mathrm{mL})$ & 14 & 8.92 & 14 & 21.1 & 49.11 & $42.95,56.15$ \\
\hline
\end{tabular}

$A U C_{\text {last }}$ area under the plasma concentration-time curve from time zero to time of last measurable concentration, $A U C_{24}$ AUC from time zero to time $24 \mathrm{~h}, C I$ confidence interval, $C_{\max }$ maximum observed plasma concentration

a The pharmacokinetic parameters were log-transformed prior to analysis, and the least-squares means, ratios and corresponding CIs of pharmacokinetic parameters were back-transformed from the log scale

$C_{\text {max }}$ values were observed when the drug was co-administered with fluconazole (15\%), ketoconazole (26\%) and bupropion $(114 \%)$, whereas a decrease of $51 \%$ in the $C_{\max }$ of vortioxetine was seen with vortioxetine/rifampicin co-administration compared with vortioxetine alone.
Similarly, increases in vortioxetine AUC values were seen with co-administration with fluconazole (46\%), ketoconazole $(30 \%)$ and bupropion (128\%), whereas co-administration with rifampicin resulted in decreases of 72 to $77 \%$ in vortioxetine AUC compared with 
Table 4 Adverse events in the bupropion study ${ }^{a}$

\begin{tabular}{|c|c|c|c|c|c|c|}
\hline \multirow[t]{2}{*}{ Adverse event } & \multicolumn{3}{|l|}{ Cohort 1} & \multicolumn{3}{|l|}{ Cohort 2} \\
\hline & $\begin{array}{l}\text { Vortioxetine } \\
\text { Days } 1-14 \\
n=30\end{array}$ & $\begin{array}{l}\text { Vortioxetine }+ \text { bupropion } \\
\text { Days } 15-28 \\
n=28\end{array}$ & $\begin{array}{l}\text { Overall } \\
n=30\end{array}$ & $\begin{array}{l}\text { Bupropion } \\
\text { Days } 1-14 \\
n=30\end{array}$ & $\begin{array}{l}\text { Bupropion }+ \text { vortioxetine } \\
\text { Days } 15-28 \\
n=28\end{array}$ & $\begin{array}{l}\text { Overall } \\
n=30\end{array}$ \\
\hline Any adverse event & $19(63)$ & $25(89.3)$ & $27(90.0)$ & $19(63.3)$ & $17(60.7)$ & $22(73.3)$ \\
\hline Headache & $4(13.3)$ & $11(39.3)$ & $13(43.3)$ & $10(33.3)$ & $8(28.6)$ & $14(46.7)$ \\
\hline Nausea & $9(30.0)$ & 12 (42.9) & $18(60.0)$ & $5(16.7)$ & $6(21.4)$ & $9(30.0)$ \\
\hline Vomiting & $3(10.0)$ & $9(32.1)$ & $10(33.3)$ & $2(6.7)$ & $5(17.9)$ & $7(23.3)$ \\
\hline Insomnia & $1(3.3)$ & $9(32.1)$ & $10(33.3)$ & $1(3.3)$ & $2(7.1)$ & $2(6.7)$ \\
\hline Dizziness & $1(3.3)$ & $7(25.0)$ & $7(23.3)$ & $3(10.0)$ & $2(7.1)$ & $4(13.3)$ \\
\hline Constipation & $3(10.0)$ & $5(17.9)$ & $7(23.3)$ & 0 & 0 & 0 \\
\hline Hyperhidrosis & 0 & $6(21.4)$ & $6(20.0)$ & $1(3.3)$ & $2(7.1)$ & $3(10.0)$ \\
\hline Palpitations & $2(6.7)$ & $4(14.3)$ & $6(20.0)$ & $2(6.7)$ & $3(10.7)$ & $4(13.3)$ \\
\hline Dyspepsia & $1(3.3)$ & $3(10.7)$ & $4(13.3)$ & $2(6.7)$ & $1(3.6)$ & $3(10.0)$ \\
\hline Tremor & 0 & $4(14.3)$ & $4(13.3)$ & $1(3.3)$ & $2(7.1)$ & $3(10.0)$ \\
\hline Abnormal dreams & $2(6.7)$ & $2(7.1)$ & $4(13.3)$ & 0 & 0 & 0 \\
\hline Agitation & 0 & $4(14.3)$ & $4(13.3)$ & 0 & 0 & 0 \\
\hline Anxiety & 0 & $4(14.3)$ & $4(13.3)$ & 0 & 0 & 0 \\
\hline Vertigo & 0 & $3(10.7)$ & $3(10.0)$ & $1(3.3)$ & 0 & $1(3.3)$ \\
\hline Fatigue & $1(3.3)$ & $2(7.1)$ & $3(10.0)$ & 0 & 0 & 0 \\
\hline Oropharyngeal pain & 0 & $1(3.6)$ & $1(3.3)$ & 0 & $3(10.7)$ & $3(10.0)$ \\
\hline URTI & 0 & 0 & 0 & $3(10.0)$ & 0 & $3(10.0)$ \\
\hline Somnolence & 0 & 0 & 0 & $3(10.0)$ & $1(3.6)$ & $4(13.3)$ \\
\hline
\end{tabular}

URTI upper respiratory tract infection

${ }^{\text {a }}$ Values are number of subjects $(\%)$

vortioxetine alone. The $90 \% \mathrm{CIs}$ for vortioxetine $\mathrm{AUC}_{24}$ and $C_{\max }$ central values were within the 80 to $125 \%$ noeffect boundary when vortioxetine was co-administered with a single dose of omeprazole (CYP2C19 inhibitor) compared with vortioxetine alone.

\subsection{Safety}

The co-administration of vortioxetine with inhibitors (fluconazole, ketoconazole and bupropion), with an inducer (rifampicin), and with CYP2C19 (omeprazole), CYP3A (ethinyl estradiol/levonorgestrel) or CYP2B6 (bupropion) substrates was well tolerated with no marked increases in the frequency of adverse events, except with bupropion. Sixteen of 60 subjects enrolled terminated the bupropion study early: nine due to adverse events and seven for withdrawal of consent. The most common adverse events in the bupropion study were nausea, dizziness, headache and diarrhea. When bupropion was added to vortioxetine monotherapy, the incidence of nausea, vomiting, insomnia and dizziness increased compared with when vortioxetine was administered alone or when vortioxetine was added to bupropion monotherapy (Table 4).

\section{Discussion}

Because many CYP isoforms are involved in the oxidative metabolism of vortioxetine (including CYP2D6, CYP3A4/5, CYP2C9, CYP2C19, CYP2A6, CYP2C8 and CYP2B6), there is potential for pharmacokinetic drug-drug interactions when vortioxetine is combined with agents that influence (i.e., induce or inhibit) these enzymes. However, the potential for CYP inhibitors to markedly affect the pharmacokinetics of vortioxetine is relatively low because multiple CYP pathways are involved in the metabolism of vortioxetine.

The present studies examined the effect of several agents that could potentially impact the pharmacokinetic parameters of vortioxetine, as well as the effect of vortioxetine on the pharmacokinetics of selected CYP substrates that likely would be co-administered with this antidepressant. Overall, the study findings demonstrate that vortioxetine has no effect on the pharmacokinetics of omeprazole (or its CYP2C19mediated metabolite), $\mathrm{COC}$ or bupropion when these agents are co-administered with vortioxetine. This suggests that vortioxetine is not an inhibitor or inducer of CYP2C19, CYP3A or CYP2B6, and therefore would be unlikely to cause a significant effect on the substrates of these isozymes. 
In addition, an exploratory in vivo cocktail study was conducted to evaluate the effect of multiple daily doses of vortioxetine $10 \mathrm{mg}$ on the pharmacokinetics of probe substrates of CYP1A2 (caffeine), CYP2C9 (tolbutamide), CYP2D6 (dextromethorphan) and CYP3A4 (midazolam) in healthy volunteers [16]. Pharmacokinetic parameters were within the no-effect boundary for the probe substrates of CYP1A2, CYP2C9 and CYP3A4, whereas vortioxetine decreased plasma exposure of dextromethorphan by up to $24 \%$.

These CYP enzyme inhibitory profiles of vortioxetine compare favorably with other currently available secondgeneration antidepressants. For example, several agents (e.g., bupropion, fluoxetine, paroxetine, duloxetine) are strong or moderate inhibitors of CYP2D6, while fluvoxamine is a strong inhibitor of CYP1A2 and CYP2C19 and a weak inhibitor of CYP2C9 and CYP3A4 [17]. These agents have clinically significant drug interactions with agents that are substrates of these CYP isoenzymes [17]. In contrast, compared with other antidepressant agents such as citalopram, escitalopram, venlafaxine and desvenlafaxine [17], vortioxetine has little to no effect on various CYP isoforms and is therefore not expected to influence drug concentrations of CYP substrates at the recommended dosages.

Modest increases in vortioxetine exposure (of 15-46 \%) were observed when the antifungals fluconazole and ketoconazole were co-administered with vortioxetine, indicating that inhibition of CYP2C9, CYP2C19 or CYP3A4/5 affects the pharmacokinetics of vortioxetine. The increases observed are not considered clinically meaningful, since no safety or tolerability issues were noted with co-administration (vs vortioxetine alone).

A higher incidence of adverse events was observed when bupropion was added to vortioxetine compared with the addition of vortioxetine to bupropion. This observation was likely associated with an increase in exposure of vortioxetine (approximately $100 \%$ ) due to the potent CYP2D6 inhibition by the two active metabolites of bupropion (threohydrobupropion and erythrohydrobupropion), which suggests that CYP2D6 is the main pathway for the metabolism of vortioxetine. The potential impact of inferred metabolic status for CYP2D6 was assessed in a phase 1 population pharmacokinetics model using data from 26 clinical pharmacology studies in 887 healthy subjects. Based on this analysis, CYP2D6-inferred metabolic status had a significant impact on clearance, with a factor of 1.9 between CYP2D6 extensive metabolizer and poor metabolizer [18], consistent with the $100 \%$ increase in vortioxetine exposure in the drug interaction study with bupropion.

In the bupropion study reported here, there was an increase in the adverse events in one subject who was a CYP2D6 poor metabolizer when bupropion was added to vortioxetine, even though vortioxetine plasma levels in this subject did not change with co-administration. Because an increase in vortioxetine exposure alone could not account for the higher incidence of adverse events when bupropion was added, a potential pharmacodynamic interaction between vortioxetine and bupropion was suspected.

All these drug interaction studies were conducted in healthy subjects; however, patients with MDD in the population pharmacokinetic analyses were shown to have similar pharmacokinetics as in healthy subjects. Based on these results, a lower dose of vortioxetine may be considered in MDD patients if strong CYP2D6 inhibitors (e.g., bupropion, fluoxetine, paroxetine, quinidine) are coadministered with vortioxetine. Rifampicin, a broad CYP inducer, decreased the exposure of vortioxetine by $72 \%$. A dose increase may be necessary when vortioxetine is coadministered in MDD patients with a broad CYP450 inducer (e.g., rifampicin, barbituates, phenytoin, carbamazepine).

\section{Conclusion}

Overall, these results indicate that adding vortioxetine has no significant effect on the pharmacokinetics of ethinyl estradiol/levonorgestrel, bupropion or omeprazole. The addition of bupropion significantly increased vortioxetine exposure, whereas the addition of rifampicin significantly decreased vortioxetine exposure; therefore, dose adjustments may be considered when these agents are coadministered. Adding fluconazole and ketoconazole modestly increased vortioxetine exposure; however, no dose adjustment is necessary due to the lack of safety or tolerability concerns. All of the investigated combinations were generally well tolerated, with most adverse events being mild or moderate in intensity.

Acknowledgments The authors would like to acknowledge Mette Graulund Hvenegaard (current Lundbeck employee) for the unpublished nonclinical in vitro data. The authors would also like to thank Michael Cwik, PhD (current Takeda employee) for his valuable contributions to the studies included in this manuscript. These studies were supported by the Takeda Pharmaceutical Company, Ltd and H. Lundbeck A/S. Assistance with writing and manuscript preparation was provided by The Medicine Group and was funded by the Takeda Pharmaceutical Company, Ltd and H. Lundbeck A/S. Drs. Chen, Lee, $\mathrm{H} \phi$ jer, Buchbjerg and Zhao are employees of Takeda Pharmaceutical Company, Ltd and H. Lundbeck A/S. At the time these studies were conducted, Dr. Michael Serenko was an employee of Takeda Pharmaceutical Company, Ltd.

Open Access This article is distributed under the terms of the Creative Commons Attribution Noncommercial License which permits any noncommercial use, distribution, and reproduction in any medium, provided the original author(s) and the source are credited. 


\section{References}

1. Bang-Andersen B, Ruhland T, Jørgensen M, et al. Discovery of 1-[2-(2,4-dimethylphenylsulfanyl)phenyl]piperazine (Lu AA21004): a novel multimodal compound for the treatment of major depressive disorder. J Med Chem. 2001;54:3206-21.

2. Mørk A, Pehrson A, Brennum LT, et al. Pharmacological effects of Lu AA21004: a novel multimodal compound for the treatment of major depressive disorder. J Pharmacol Exp Ther. 2012;340:666-75.

3. Henigsberg N, Mahableshwarkar AR, Jacobsen P, Chen Y, Thase ME. A randomized, double-blind, placebo-controlled 8-week trial of the efficacy and tolerability of multiple doses of Lu AA21004 in adults with major depressive disorder. J Clin Psychiatry. 2012;73:953-9.

4. Jain R, Mahableshwarkar A, Jacobson P, Chen Y, Thase ME. A randomized, double-blind, placebo-controlled 6-wk trial of the efficacy and tolerability of $5 \mathrm{mg}$ vortioxetine in adults with major depressive disorder. Int J Neuropsychopharmacol. 2013;16:313-21.

5. Mahableshwarkar AR, Jacobsen PL, Chen Y. A randomized, double-blind trial of $2.5 \mathrm{mg}$ and $5 \mathrm{mg}$ vortioxetine (LuAA21004) versus placebo for 8 weeks in adults with major depressive disorder. Curr Med Res Opin. 2013;29:217-26.

6. Donato MT, Castell JV. Strategies and molecular probes to investigate the role of cytochrome P450 in drug metabolism: focus on in vitro studies. Clin Pharmacokinet. 2003;42:153-78.

7. Lin JH, Lu AY. Inhibition and induction of cytochrome P450 and the clinical implications. Clin Pharmacokinet. 1998;35:361-90.

8. Hisaka A, Kusama M, Ohno Y, et al. A proposal for a pharmacokinetic interaction significance classification system (PISCS) based on predicted drug exposure changes and its potential application to alert classifications in product labelling. Clin Pharmacokinet. 2009;48:653-66.

9. Schellander R, Donnerer J. Antidepressants: clinically relevant drug interactions to be considered. Pharmacology. 2010;86: 203-15.
10. Hvenegaard MG, Bang-Andersen B, Pedersen H, et al. Identification of the cytochrome P450 and other enzymes involved in the in vitro oxidative metabolism of a novel antidepressant, $\mathrm{Lu}$ AA21004. Drug Metab Dispos. 2012;40:1357-65.

11. Areberg J, Søgaard B, Højer AM. The clinical pharmacokinetics of $\mathrm{Lu} \mathrm{AA} 21004$ and its major metabolite in healthy young volunteers. Basic Clin Pharmacol Toxicol. 2012;111:198-205.

12. Nilausen D, Højer A-M, Bendahl L. Absorption, metabolism, and excretion of an oral dose of [14C]-Lu AA21004 $50 \mathrm{mg}$ in healthy men. J Clin Pharmacol. 2009;49:1113.

13. Brown HS, Galetin A, Hallifax D, et al. Prediction of in vivo drug-drug interactions from in vitro data: factors affecting prototypic drug-drug interactions involving CYP2C9, CYP2D6 and CYP3A4. Clin Pharmacokinet. 2006;45:1035-50.

14. von Moltke LL, Greenblatt DJ, Schmider J, et al. Metabolism of drugs by cytochrome P450 3A isoforms. Implications for drug interactions in psychopharmacology. Clin Pharmacokinet. 1995; 29(suppl 1):33-44.

15. Zhou S, Yung Chan S, et al. Mechanism-based inhibition of cytochrome P450 3A4 by therapeutic drugs. Clin Pharmacokinet. 2005;44:279-304.

16. Wang Y, Wojtkowski T, Hanson E, et al. An open-label, multiple-dose study in healthy adults to assess the drug interaction potential of Lu AA21004 using the Indiana cocktail. J Clin Pharmacol. 2009;49:1114.

17. Spina E, Trifiro G, Caraci F. Clinically significant drug interactions with newer antidepressants. CNS Drugs. 2012;26:39-67.

18. Areberg J, Naik H, Chen G, Pedersen KB, Vakilynejad M. A population pharmacokinetic meta-analysis of vortioxetine ( $\mathrm{Lu}$ AA21004) in healthy subjects. Poster presented at the 12th International Forum on Mood and Anxiety Disorders (IFMAD), Barcelona, Spain, November 7-9, 2012. 